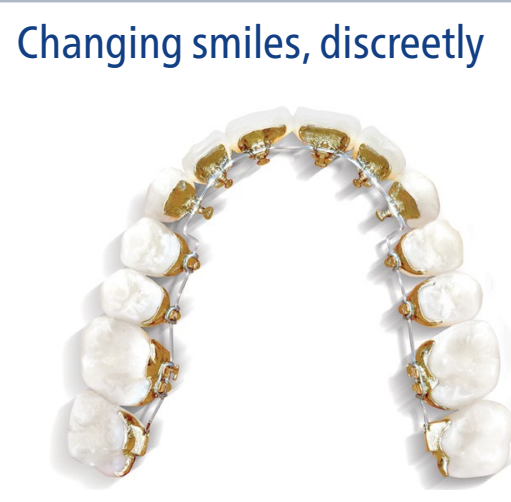

You may be experiencing more enquiries about orthodontics, as patients want to invest in improving their smile.

With the Incognito Appliance System from 3M Oral Care, your patients won't have to feel self-conscious about wearing an appliance, because it is fitted behind the teeth.

It will be customised to the oral cavity and will gently move their teeth into the desired position. The results will be predictable, enduring and even life-changing, offering an ideal solution for a range of patients.

With the Incognito Appliance System they can go about their daily lives knowing that they are on the path to achieving the smile of their dreams.

To find out how you can offer this system at your practice, contact the $3 \mathrm{M}$ team today.

For more information, call 08458734066 or visit http:// solutions.3m.co.uk/wps/portal/3M/ en_GB/orthodontics_EU/Unitek/.3M representatives continue to be available via video calling technologies for your convenience.

$3 \mathrm{M}$ and Incognito are trademarks of the $3 \mathrm{M}$ Company.

\section{Powerful protection in all areas}
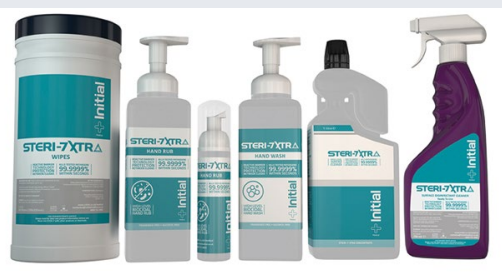

In a dental practice, infection control is of vital importance. As such, you need cleaning products that not only effectively

\title{
All your questions answered
}

If you have heard about the Waterpik Water Flosser, but want to know more about how it could elevate your patients' oral hygiene, a Lunch \& Learn is just want you need!

You can book a 1-hour slot with one of our Professional Educators, who will present all the scientific data supporting the Waterpik Water Flosser and demonstrate its key benefits. They will be able to answer any of your questions and offer advice on how to maximise the advantages available specifically for all your patients.

Your practice will even get a free

Waterpik Water Flosser demo model when you sign up.

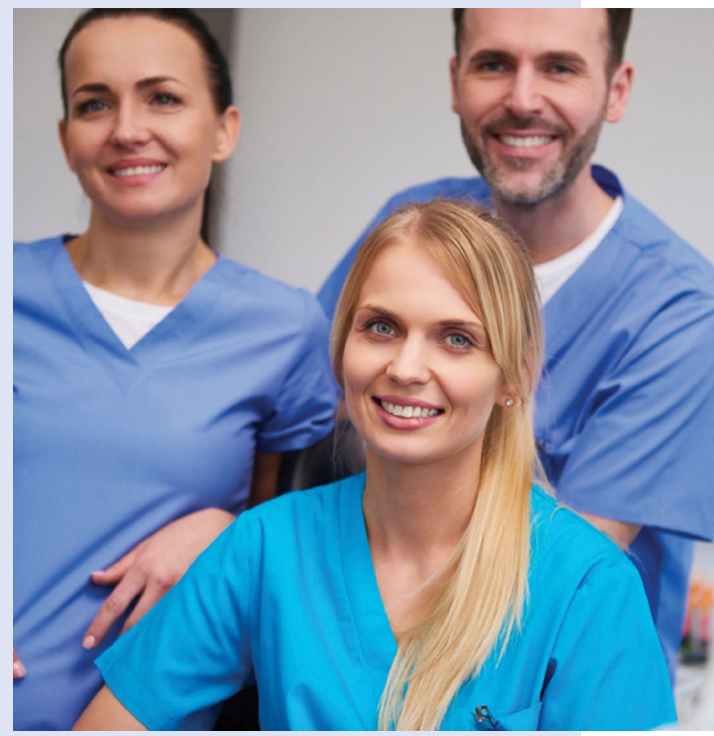

Now available virtually or in person - where is it safe to do so - Waterpik Lunch \& Learns are the ideal way for you to get all the answers you need. Book yours today!

For more information on Waterpik products visit www.waterpik.co.uk. Waterpik products are available from Amazon, Asda, Costco UK, Argos, Boots, Superdrug online and in stores across the UK and Ireland.

Book a Waterpik professional Lunch and Learn for one hour of verifiable CPD and a free Waterpik Water Flosser - available either face to face or as a webinar - at www. waterpik.co.uk/professional/lunch-learn/.

\section{Are the new dates in your diary yet?}

Have you heard? The next British Dental Conference and Dentistry Show will be held on Friday 13 and Saturday 14 May 2022, at the familiar venue of the Birmingham NEC.

The show will once again bring a packed two-day programme for all members of the dental team to enjoy. With hours of verifiable $\mathrm{CPD}$, world-class speakers, a dynamic selection of topics and discussions, as well as the chance to discover new innovations and socialise with colleagues, it really will have it all.

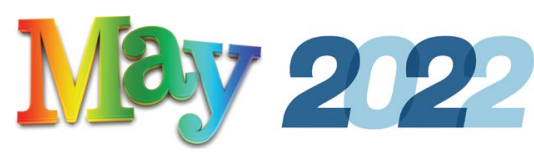

As we prepare for a better year than last, make sure you get the dates in your diary so you don't miss out in 2022.

The next British Dental Conference and Dentistry Show will be held on Friday 13 and Saturday 14 May 2022, Birmingham NEC, co-located with DTS.

For more information, visit www. thedentistryshow.co.uk, call 02073485270 or email dentistry@closerstillmedia.com. eliminate threats, but can also be used on a variety of surfaces and delicate equipment.

The Steri-7 Xtra range of disinfectants from Initial Medical is a dependable choice.

The range comprises surface cleaners, handwashes, wipes and more, meaning that solutions can be efficiently used across every surface in your practice. Furthermore, even though the powerful formula kills $99.9999 \%$ of bacteria, viruses and other pathogens, it is still gentle enough to be used on delicate equipment.

As an added bonus the Steri-7 Xtra range is imbued with Reactive Barrier Technology - this means that after application they prevent pathogens from recolonising surfaces for up to 72 hours - providing exceptional protection between cleaning cycles.

For further information visit www. initial.co.uk/medical or Tel: 08708504045 . 